\title{
Antonio Gramsci's role in Marxian thought and the contribution made to international relations by those using his ideas
}

Egni Malo, MA

London Metropolitan University, London, UK

\begin{abstract}
Some of the most promising post-Cold War developments in Marxian thought have been stimulated by problems facing Marxists in Western Europe, to that extent they all seem to lay bare, intentionally or otherwise, the lacking of qualities, of Marx's prediction. The most significant example of the failure of Marxist theory to be realised in practice is the persistent survival of the capitalist mode of production. The inevitable crisis foreseen by Marx, which would lead to revolution, failed to materialise and that claim is now itself historical, since capitalism has become the norm for social organisation in most of the world's nations. By asking the question how capitalism can persist amid crisis, Gramsci, provided the most promising way of revision to the stunted Marxian orthodoxy. Today for us is important to ask whether Marxist analysis of neoliberal global strategy or globalisation and fragmentation invite reconsideration of the tendency on the part of many international relations scholarships to ignore and simply dismiss Marxism. It is also important to consider whether the significance of Marxist project of developing a critical approach to international politics, is but one way in which Marxism progressed beyond the traditional Anglo-American scholarship to IR.
\end{abstract}

Keywords: Gramsci, Marxism, International-Relations, Neo-Gramscian, Hegemony, Capitalism, World-Order

\section{Introduction}

Antonio Gramsci (1891-1937) the Italian political activist and theorist is not an immediate lead in the studying of International Relations(IR). Yet Gramsci pursued a path of political activism and intellectual innovation, which gives his work a contemporary significance with regard to the working class conquest of power and subsequent transformation of society. From the second half of the twentieth century - with the translations of Prison Notebooks appearing in the West in $1971^{1}$ - many independent critically inspired writers particularly in the early 1980s have studied the Notebooks to challenge the dominance of status-quo perspectives that defined the content and

${ }^{1}$ Quintin Hoare and Geoffrey Nowell Smith, Selections from the Prison Notebooks of Antonio Gramsci, (1971), trans, and eds. London: Lawrence and Wishart 
the conditions of further study in the subject matter of IR. ${ }^{2}$ Attempts nonetheless, to apply the critical method of Marxian historical thought as derived from Gramsci can be found in many works particularly in the theoretical developments of Robert W, Cox and what become known as the academic compass of Neo-Gramscianism.

The use of Gramsci's political theory to examine International Relations and International Political Economy has been the subject of a great deal of discussion. These discussions however tended to generate somewhat more confusion than a straightforward interpretation. Much of the debate has focused on the problematic of whether Gramsci's work is in fact relevant for the international domain and within that whether, writers like the neo-Gramscians have appropriated Gramsci's concepts properly. The debate is characterized by a complicated legacy of interpretation of Gramsci's work in which specific questions, like how did Gramsci define the 'state' or 'civil society', intersects with broader methodological and ideological concerns, like was Gramsci ultimately a Marxist? While Marx is found guilty of a negative conception of the state in failing to analyse the ideological and political aspects of power, Gramsci it is argued, insisted that politics involves not merely coercion but consent too. ${ }^{3}$ Under these circumstances coercive force recedes into the background and not apparent on everyday political life. So based on the critical tone that some writers associate with Gramsci, as the inaugurator of a new chapter in Marxist politics the relation of Marx to Gramsci then becomes problematic ${ }^{4}$ : where does Gramsci's position stand in relation to that of Marx?

In this work we attempt to add an important and up to date contribution to the academic debates which utilise Gramsci's thought for theoretical support and will be of relevance to students and scholars of political philosophy, economics, post-colonial studies and international relations. The objective is in initiating an original debate across political and international theory on the thought and practice of Antonio Gramsci in a way that lays bare clear contentions for present and future discussion. We hope to make a valuable contribution by interrogating the cognitive high theory, and offer the scholarly literature an introduction to and an illustration of the promise of the Gramscian insights to IR. Furthermore we seek to disperse on the parameters of the apparently intractable debates of the nature of Gramsci's work in IR/IPE. Those parameters seem to reproduce precisely the kind of ontological split that Gramsci's theorization of revolutionary potential in the face of the integral state, situated in an international capitalist order, sought to overcome. We are particularly concerned with Neo-Gramscian claim that Gramsci, unlike Marx recognised that political authority

\footnotetext{
${ }^{2}$ These new interpretations of Marxist International theory have enlarged the perspective and given it an important weapon in the critique of Realism, by offering innovative attempts to use Marxist ideas to develop a more historically aware conceptions of the modern IR: for example in the writings of Cox 1981; Gill 1993; Halliday 1994; Rosenberg 1994 etc.

${ }^{3}$ Miliband, R. (1977), Marxism and Politics, Oxford: Oxford University Press, pp43.

${ }^{4}$ Hobsbawm, E. (1977), Gramsci and Political theory, Marxism Today, pp205-13
} 
involves both coercion and consent. By returning to Gramsci's Prison Notebooks, particularly his analyses of hegemony and the concept of passive revolution, (top-down process designed to discourage popular resistance that might otherwise present itself as an alternative or transformative role), we attempt to offer a more robust account of the uneven operation across multiple levels from the global to the local. This provides a critical perspective that allows us to explore the way the current discussions run aground due to unwillingness of accepting Gramsci's historical materialist ontology. This is an interpretative exploration, by all means not a systematic exposition. My argument is that both Marx's and Gramsci's views are actually much closer than is usually acknowledged and that neo-Gramscianism does not fully represent Gramsci's Marxism.

\section{Prison Notebooks: Neo-Gramscian analyses of the International System}

The influences of Gramsci's arguments are a telling, of his understanding of the tensions between the domestic-external dimensions, in which the external developments stimulate the context for restructuring and instigating domestic change. Gramsci might have been motivated by the same type of ideas as Lenin or Bukharin, though, he did not put forward imperialist analysis, and in fact he provided a critique, to the economic determinism. Thus, Gramsci focused instead on the mechanisms of ideological transmission and not in the rivalry produced by the processes of capital accumulation, imperialist expansionism and war. Contrary to conventional Marxian thought that even in our time assumes social relations and the state in their particular national dimensions, Gramsci sensed that the national and the international are intricately linked and that Marxism must instead focus on how "the international situation should be considered in its national aspect". ${ }^{5}$ Gramsci extended the revolutionary possibility to the international realm, in a sense that he understood perfectly well that the world capitalist system should be countered across national boundaries. Yet, while 'the perspective is international and cannot be otherwise', capitalism's uneven development produces elements of national 'originality and uniqueness' which must be the concrete point of departure if the workers' movement is to engage in effective struggle: the workers' movement must "nationalise" itself in a certain sense'. ${ }^{6}$ In the Italian context, this required the establishment of working class hegemony or leadership over notably peasant masses in southern Italy. The task of working class alliance with the peasant masses was to counter the privileges and undue influence of the elites. Gramsci understood this process in terms of the passive revolution, meaning, the adoption of laws and rights designed to pacify the revolutionary potential of the masses. Capitalist elites Gramsci argued could extend their reach over the civil society by implementing anew, whatever necessary legislation to maintain

\footnotetext{
${ }^{5}$ Prison Notebooks, pp182, pp317
}

${ }^{6}$ Prison Notebooks, pp240 
their control. This pacification effectively politicized the civil society and undermined its relative autonomy. Therefore, in order to oppose the hegemonic control and thus ensure that civil society served the interests of the oppressed masses, the workers and peasant alliance needed a counter-hegemonic civil society.

Passive revolution describes a top-down process in which a narrow, modernizing elite brings about transformation of traditional social relations by piecemeal reform. Unlike the Jacobins in the French Revolution, it failed to mobilize mass activity behind its revolutionary aims. The pressure behind this process arose not from domestic economic development, but was instead the reflection of international developments which transmit their ideological currents to the periphery currents born of the productive development of the more advanced countries'.7 Similarly, Gramsci argued that the Fordist development of early 20th century American industry, itself a passive revolution that transformed existing forms of capitalist relations, was reshaping European societies and forcing states to adopt structures and policies more supportive of free enterprise and economic individualism. ${ }^{8}$ Gramsci also suggested that Italian fascism represented a passive revolution designed to preserve the power of a decaying bourgeoisie faced with the revolutionary challenge from Russia.

Gramsci's notion of hegemony offers an analytical framework within which to better understand and challenge the entrenched interests of capital in society and a way of thinking about creating the conditions for political change. The establishment of hegemony nationally is treated broadly in Gramsci's writings though he extends his appliance to hegemony and particularly to the French effort on establishing leadership over Europe in the nineteenth century. ${ }^{9}$ It is in Gramsci's concept of hegemony internationally that neo-Gramscianism finds its inspiration. Robert W. Cox, the intellectual root of neo-Gramscianism, has most notably build a convincing critical, theoretical ground based on Gramsci's concept of hegemony. ${ }^{10}$ Cox's, conceptual vocabulary of hegemony highlights a contested relation of social power all inclusive of cultural, economic and political facets of social life and possibly spanning transnationally. Critical Gramsci, rediscovered by Cox became a pillar by other pioneering scholars for establishing the credibility of this of approach to the study of world politics. Augelli and Murphy set out Gramscian notions of ideological struggle and hegemonic power to better explain global inequality and the emergence of neoliberal market orthodoxy. ${ }^{11}$

\footnotetext{
${ }^{7}$ Prison Notebooks, (1971), pp116-117

${ }^{8}$ Prison Notebooks, pp293

${ }^{9}$ Prison Notebooks, pp240-241

${ }^{10}$ See Robert Cox founding works in enlarging Gramscian thought, Social Forces, States and World Orders: Beyond International Relations Theory, in Millennium: Journal of International Studies, Vol. 10, No. 2 (1981), and also Gramsci, Hegemony and International Relations: an Essay in Method, in Millennium: Journal of International Studies, Vol. 12, No. 2, (1983).

${ }_{11}$ In their writings they used the Gramscian approach to understand the resistance to the North-South structure of global scale partiality posed by the ideologies allied with the New International Economic Order in the 1970s and the ways which this movement's efforts were undercut by the global debt crisis and re-emergence of global hierarchies. See Augelli, E. \& Murphy, C. (1988), America's Quest for Supremacy and the Third World, London: Pinter
} 
In the process of establishing this neoliberal hegemony the important role of the transnational groups such as the Trilateral Commission was demonstrated in the seminal study by Gill, who coined the phrase "disciplinary neoliberalism" to describe the operation of this market fundamentalism. ${ }^{12}$ Neo-Gramscians scholarship focused also on the role of industrial development and the emergence of international forums and the social construction of US hegemony in the twentieth century. ${ }^{13}$ Robinson on the other hand later stressed the effects that the weak form of democracy related to the minimal social participation had upon the reproduction of the global hegemony in the developing nations as the twentieth century came to its end. ${ }^{14}$ More recent writers, reflecting on Cox's efforts to apply Gramsci's concepts to the international level, have also produced important studies to critique the statist concepts of realism and interstate relations. ${ }^{15}$

The Prison Notebooks enables neo-Gramscianism to demolish many central Realist arguments at the international level. Gramsci's writings have provided neoGramscianism with three particular strengths in analyzing the contradictions inferred by capitalism and its neo-liberal orthodoxy. For a start Neo-Gramscians have proved very potent in countering major Realist claims, by recognizing as central class forces that develop through production processes; contrary to Realist assumptions that see the state purely as the rational expression of national interest. By basing state power in class relations the neo-Gramscians are in line with both Gramsci's view that international relations are intertwined fundamentally with social relations and his view of the state as terrains of struggle. Cox therefore has argued that states are not the only entities of the international system, furthermore the international system is not an inter-state system: it must be understood in a more relational, active and potentially changing set of relations between, social forces; forms of state; and world order. Social forces, forms of state and world orders were integral to one another's historical construction. Secondly, Gramsci purely rejected an instrumentalist interpretation of Marxist thought that sees man mechanically react to their material reality. Neo-Gramsianism too, follows this logic in recognizing that ideas themselves are part of the circumstances of that material life and in one of the very famous quotes to any international relations student, Cox stated that "theory is always for someone and for some purpose". ${ }^{16}$ What this means is that mainstream theory is ideologically biased and permanently interested in keeping with the existing social structures of

\footnotetext{
${ }^{12}$ Gill, S. (1995), Globalisation, Market Civilisation, and Disciplinary Neoliberalism, Millenium: Journal of the International Studies 24: p422 and pp399-423.

${ }^{13}$ Rupert, M. (1995), Producing Hegemony, Cambridge: Cambridge University Press

${ }^{14}$ Robinson, W. (1996), Promoting Polyarchy, Cambridge: CUP

${ }^{15}$ These writers have sometimes reflected critically on the neo-Gramscian scholarship and its relevance for the contemporary global politics, see Paul, D. (2005), Rescaling International Political Economy, London: Routledge; also Bieler, A. \& Morton, A. (2006) (eds.) Images of Gramsci, London: Routledge

${ }^{16}$ Robert Cox, (1981), Social Forces, States and World Orders: beyond international relations theory, in Robert Cox and Timothy Sinclair (eds), Approaches to World Order, Cambridge: CUP pp87.
} 
power; solve the problems within the structure rather change. This leads to a further intellectual vigor within the neo-Gramscian approach, to its engagement of realizing social change. Neo-Gramscianism reflects the contradictions within the existing social relations that are feasible basis for an alternative change. Cox endorses thus Gramsci's view that the reality is not ahistorical, "static or immobile" but "a relation of forces in continuous motion and shift of equilibrium". ${ }^{17}$

The neo-Gramscians similarly to Gramsci have aided Marxist ideas in international analysis, although, by approaching idealistically the concept of hegemony arguably shows that they are inaccurate in interpreting for Gramsci's Marxism, which explains therefore their vain analysis of the dynamics of the international system. It might be argued that Gramsci's immense contribution to IR theory is patchy - rather underdeveloped in the Global Political Economy, (GPE) literature - and that NeoGramscian stance is structured at odds with the dialogic conception of philosophy which it argues. Cox explains that a combination of the reciprocal relationships of political, ethical and ideological spheres of activity, with the economic sphere, avoids reducing everything to crude economics, thus advancing Marx's reductionist theory. ${ }^{18}$ This would mean that where the hegemonic class is the dominant class in society, the State maintains cohesion and identity within the bloc through the proliferation of a common culture. So rather than engaging with the interactions, fruitful or botched, of the revolutionary Marxists with common sense of the working class, it takes its markers from the debates in Marxist, post-Marxist, and Marxian academia, as if those constituted "Marxism", in abstraction from political practice. ${ }^{19}$ It is a sad symptom of the poverty of Marxist thought today that the various sides, (including neoGramscianism), have entered this debate not by assessing Gramsci's contributions to Marxism as a whole, but by wrenching odd categories of paragraphs out of context and using them to justify major points of contention. Despite the strengths of neoGramscianism, and the fact that some neo-Gramscians mobilize Marxist arguments more systematically than others, there are major problems with the neo-Gramscian perspective. ${ }^{20}$ In particular, its approach to international hegemony deviates in important ways from a Marxist understanding of the capitalist world system, seriously diminishing its explanatory power. ${ }^{21}$

\footnotetext{
${ }^{17}$ Prison Notebooks, as above, pp272.

${ }^{18}$ See Cox in Gill, S. (ed.) (1993), Gramsci, Historical Materialism and International Relations, Cambridge: Cambridge University Press, pp56.

${ }^{19} \mathrm{http}: / /$ www.workersliberty.org/story/2011/06/15/gramsci-revolutionary-socialist-democratic-philosopher

${ }^{20}$ See Mark Rupert for example, he uses Marxian arguments regularly in his analysis, Alienation, Capitalism and the Inter-state System: Towards a Marxian/Gramscian Critique, in Stephen Gill (1993), Gramsci, Historical Materialism and International Relations,. Cambridge: CUP.

Gill's methodical manner on the other hand resembles the unanticipated disaster of academic Marxism. His writing in, for instance, The Socialist Register, is particularly insightful and crucial to critical analysis of ruling classes see Intellectuals and Transnational Capital, Vol. 26, (1990), pp290-1.
}

${ }^{21} \mathrm{http}: / /$ www.isj.org.uk/index.php4?id=309\&issue=114 


\section{Hegemony}

Neo-realist hegemonic stability theory argues that international order may exist provided it rests on one powerful state, which dominates all other states through its preponderance in military and economic capabilities. ${ }^{22}$ By contrast, the neo-Gramscian perspective developed by Cox broadens the domain of hegemony. ${ }^{23}$ Hegemony is a form of dominance, but it refers more to a consensual order so that 'dominance by a powerful state may be a necessary but not a sufficient condition of hegemony'. ${ }^{24}$ It becomes more than simply state dominance. As anticipated, the concept of hegemony has two meanings: "the supremacy of a social group manifests itself in two ways, as 'domination' and as 'intellectual and moral leadership'." 25 The key distinction is that the former is top-down hegemony (political society over civil society); whereas the latter is bottom-up (civil society reaches political society). Where Gramsci discusses "consent" and "coercion" as aspects of leadership, neo-Gramscian, social-reformist interpretation has seen them as mutually-exclusive alternatives. Firstly, coercive force is manifested through direct force or a threat thereof, which the State employs when its degree of hegemonic leadership is in decline. Secondly, consensual control arises when individuals voluntarily digest the worldview of the dominant group, resulting in hegemonic leadership. Where the hegemonic class is the dominant class in society, the State maintains cohesion and identity within the bloc through the proliferation of a common culture. Neo-Gramscians argue that modern capitalist rule rests largely on "consent", therefore, that all strategy must be directed at "consent". They conclude that winning wide "consent" by a sort of diffuse coalition-building is what "hegemony" really means. ${ }^{26}$

Despite its broad political and ethical reading of hegemony, which opens a space for an analysis of the state, this space is immediately and almost permanently preoccupied by the synoptical gaze of capitalism. The 'state' is rendered too gladly as the mere accommodator and developer of home grown capitalisms. The internationalisation of the state and production are explained principally as a function, a tributary to the globalising tendencies of Capital. Moreover it is contended that the logic of capital stretches the state to the point that it then becomes a subject to global governance. Although what constitutes order is not merely a question of who supports it, but also a basis of resistance to the global capital, this pattern of argument leads neo-Gramscians to overlook the fact that the state itself despite its distinctive individualistic character is a global practice from its inception: an outcome of cultural, social and economic evolution among societies and enthused by their interaction, for more than two

\footnotetext{
${ }^{22}$ Gilpin, Robert (1981) War and Change in World Politics, Cambridge: Cambridge University Press.

${ }^{23} \mathrm{http} / / /$ www.internationalgramscisociety.org/resources/online_articles/articles/bieler_morton.shtml

${ }^{24}$ As above Cox, (1981), p139

${ }^{25}$ Prison Notebooks, (1971), pp57

${ }^{26}$ http://www.workersliberty.org/story/2011/06/15/gramsci-revolutionary-socialist-democratic-philosopher
} 
centuries now. ${ }^{27}$ The state system as a whole has been one of interaction with what is its external world, the international field, particularly from the expansion since the end of the nineteenth century of financial and industrial power across the world. Thus the logic of the state system, with its own processes and purposes aside serving as political community is not sufficiently stressed. A new order can only be established upon and out of the political economic space that arises within the intertwined logic of capital and the state system.

Gill and Law particularly distinguish between Gramsci and Lenin, when they argue that Leninism sought 'to capture state power and then shape the state and society from above', while Gramsci was committed to 'the building of socialism from below'. ${ }^{28}$ However the fact is that Gramsci was very appreciative of Lenin, whose emphasis on the relevance of political and cultural hegemony stood 'in opposition to the mechanistic and fatalistic concepts of economism'. Lenin's Marxism 'consists precisely in the historico-political concept of hegemony'. ${ }^{29}$ Lenin and Gramsci both had tactical similarities which yielded an essentially identical political practice. On the one hand Lenin encouraged the immature Comintern against hasty attempts to seize state power without first winning majority support among both workers and the wider subordinated classes. Gramsci on the other hand reflecting upon the workers' struggles of 1919-20 in Turin, argued that 'the social basis of the proletarian dictatorship and the workers' state' depend upon the creation of class alliances enabling it 'to mobilize the majority of the working population against capitalism and the bourgeois state'. ${ }^{30}$

In the face of the convenient conceptual likeness between Lenin and Gramsci, an important difference appears in the Notebooks. Gramsci extended his concept of hegemony not only to relations between the working class and other minor classes, but also to relations between antagonistic classes. While an hopeful ruling class, presenting its struggle against pre-capitalist relations and exercise leadership over other lower classes to secure its rule, once in power it should not simply seek to dominate, but must 'continue to "lead" as well'. ${ }^{31}$ Thus, while Gramsci defined hegemony as 'the combination of force and consent', and while he continually refers to coercive methods that are at the heart of class rule, even under hegemony, his usual definition as simply 'intellectual and moral leadership' reduced the coercive element in class rule. The consequence of this was Gramsci's argument that subordinate classes give their 'active' or 'spontaneous' consent to capitalist rule. ${ }^{32}$ These arguments

\footnotetext{
${ }^{27}$ Picciotto,Sol, The Internationalization of the State Review of Radical Political Economics, Vol. 22 28-44 SAGE; See also Skocpol, Theda. (1979), States and Social Revolutions, Cambridge: Cambridge University Press,

${ }^{28}$ Stephen Gill and David Law, (1988), The Global Political Economy: Perspectives, Problems and Policies, London: pp63.

${ }^{29}$ Hamish Henderson, (1988), Antonio Gramsci: Prison Letters, (ed), London: pp214.

${ }^{30}$ Lenin, cited in Perry Anderson, (1976), The Antinomies of Antonio Gramsci, in New Left Review 100, Nov-Dec, p.59; Antonio Gramsci, (1957) The Modern Prince and Other Writings New York, pp30-31.

${ }^{31}$ Prison Notebooks, (1971), pp58

32 Prison Notebooks, pp277.
} 
however, should be understood not as the definitive statement of Gramsci's views but as Gramsci's effort in convincing the Italian Communist's in continuing the struggle for hegemony, rather than follow the Comitern's disastrous extremist 'Third Period' perspective after $1928 .{ }^{33}$

A more precise indication of Gramsci's theorization is implicitly expressed in the Notebooks Gramsci analyzed the working class's 'contradictory consciousness', uniting dialectically traditionalist 'common sense' with an hostile 'good sense' drawn from firsthand understanding and forms of collective activity that really are the kernel for the 'practical transformation' of society. ${ }^{34}$ Neo-Gramscians, consistently argue that the ruling class's 'intellectual and moral leadership' is accepted by the working class. Cox makes the argument that the ruling class is hegemonic where 'the weak accept the prevailing power relations as legitimate', while Gill refers to subordinate classes' 'active consent' to bourgeois rule, albeit that this demands that the ruling class make some concessions to their interests. ${ }^{35}$ Gill and Law go further still, suggesting the possibility of a consensus constructed 'on the basis of shared values, ideas and material interests'. ${ }^{36}$ Perry Anderson on the other hand has been a prolific critique of the beliefs that power in western capitalism resides preciesly in the ideological and cultural hegemony and dismissed those beliefs as 'the involuntary temptation that lurks in some of Gramsci's notes' ${ }^{37}$ It is this interpretation of Gramsci's writings that the neo-Gramscian explains the dynamics of international relations in general. Just as the idea, of 'intellectual and moral leadership' ignores more concrete economic and political realities that better explain domestic capitalist stability, so is its explanatory power, limited at the international level.

\section{Coxian insights of the post-1945 world order}

Cox explains the post-WW-Il world order as hegemonic, as one in which power is largely consensual. For what is generally accepted is that Western European states broadly accepted and largely invited US plans for the reconstruction of a more open world economy. As the rivalries of the early part of the century became demilitarized

\footnotetext{
${ }^{33}$ See Abercrombie, Hill, Turner, (1980), The Dominant Ideology Thesis, London, present a convincing critique of the argument that bourgeois ideology dominates working class consciousness. Additionally, Therborn identified 'ideological mechanisms of subjection' more closely related to workers' lived experiences than bourgeois ideology. See Therborn, (1980), The Ideology of Power and the Power of Ideology, London; Hallas, argues that the Comintern reflected the USSR's Stalinist ruling class, contrary to the politics of Lenin and Gramsci, the Communist parties were politically passive and isolated from the wider labour movement. Thus political instability was minimized among the USSR's neighbors' and the confidence of the right was strengthened, including, of course, in Germany where the failure to pursue a United Front strategy allowed fascism to come to power, Hallas, D. (2008) ( $2^{\text {nd }}$ eds.), The Comintern: A History of the Third International, Chicago: Haymarket Books.

${ }^{34}$ Prison Notebooks, (1971), pp333

${ }^{35}$ Robert Cox, Social Forces, States and World Orders, as above, p99.

Stephen Gill, Epistemology, Ontology and the "Italian School", in Stephen Gill, Gramsci, Historical Materialism and International Relations, as above, p40.

${ }^{36}$ Stephen Gill and David Law, The Global Political Economy, as above, p78

${ }^{37}$ Perry Anderson, (1976), The Antinomies of Antonio Gramsci, New Left Review 100, Nov-Dec, pp.41
} 
and the imperialistic sentiments settled out, it did not mean however that economic rivalries were transcended. In addition we might argue that it was the effects of European opposition that forced a substantial moderation to the American strategy of seeking capitalist global expansionism. As the postwar era progressed after the 1960s the balance of change became unavoidable for the transatlantic relations, in a series of economic and political quarrels. If the continuance of rivalry might be thought to undermine Cox's definition of a consensually integrated world order, his focus on the West alone, separated from the wider structures of superpower imperialism, makes us believe a completely misleading picture of the post-war era. ${ }^{38}$ The natural consequence of Cox's definition of hegemonic order is that 'the more that military force has to be increased and the more it is actually employed, the less the world order rests on consent and the less it is hegemonic'. ${ }^{39}$ So in dismissing the Realist assumption on the might of military power in shaping the international system, Cox obliterates Realism all together as the determining factor in the cold war: amid the reality that the militarized superpower conflict was the most dominant feature of the world order post-1945. It's only within the Cold War context that the US aspired to institute its ascendancy over the rest of the advanced capitalist world; its capacity to ensure solidarity rested crucially on its military defence of Western interests against any attempt of USSR's expansionism. It is more sensible to think that if such an 'intellectual and moral leadership' of the American role in the west existed, it might have been very dependable on the more material factors, what Davis suggested as 'nuclear imperialism'. ${ }^{40}$

A further motive underlying the wide-western relative harmony that Cox acknowledges is the long boom and high levels of global economic profitability, of the post-war years. Although Cox has used in his analyses the traditional Keynesian understanding for the boom as being nourished by expansionary economic policies this is still not satisfactory, particularly since, fiscal policies were mildly deflationary during the long economic boom. ${ }^{41} \mathrm{~A}$ more sound explanation that led to high rates of global growth might be accounted as the result of economic mobilization, counterpart to the rivalry of the superpowers; this was after all, as Arrighi explains, "the most massive rearmament effort the world had ever seen in peacetime" ${ }^{42}$ Hence, the military aspect of world order was relevant in two respects that are undermined from the idealist concept of 'intellectual and moral leadership'. One, that the military pre-eminence, afforded the US with a central political mechanism for leadership of the West, and

\footnotetext{
${ }^{38}$ See Peter Burnham for the early postwar years, (1990), The Political Economy of Postwar reconstruction, London.

${ }^{39}$ Robert Cox, (1987), Production, Power and World Order: Social Forces in the Making of History, New York, pp.289.

${ }^{40}$ Mike Davis, From Fordism to Reaganism: The Crisis of American Hegemony in the 1980s', in Bush, Johnston and Coates, (1987), The World Order: Socialist Perspectives, Cambridge, pp8.

${ }^{41}$ Chris Harman makes some very different analysis that account for the long boom, see his (1999), Explaining the Crisis, London, chapter 3.
}

${ }^{42}$ Giovanni Arrighi, (1994), The Long Twentieth Century, New York, pp297. 
second, its economic growth that resulted from the massive armament helped pacify the intra-Western rivalry that may well have intensified in more economically difficult circumstances. Indeed, as profit rates declined and the boom faltered from the late1960s, transatlantic tensions deepened, the US pursued unilateral economic measures detrimental to the interests of its Western allies, and US politicians demanded revision of the terms of Western interdependence.

Cox in his analysis of the post-war order notes the decline of American hegemony and its limitations of power although he fails to relate this to the renewed global economic crisis in the 1970s. He sees this as an era of transnationalisation, as the formation of a new historic bloc, in which the state has become a sort of tributary to this process most generally known to us as globalization, for which has arguably began much earlier than the 1970s. Accordingly under this process of transnationalisation states have "willy-nilly became more effectively accountable to a nebulous personified as the global economy". ${ }^{43}$ Contrary to this view again, far from occurring regardless and diminishing state power, globalization is itself part of the sustained neoliberal ruling class advocated and practiced by the likes of Regan and Thatcher and their heirs in orchestrating state power against important sections of national labour movements across the advanced industrial states. These types of social struggles are rarely mentioned in the neo-Gramscian literature, in fact in more recent writing Cox has stated, "the restructuring of world society...challenges the Marxist schema of the primacy of class-oriented identities". ${ }^{44}$ This might be because of Cox's refusal of understanding of class as the objective expression of exploitation. This further explains why class-based analyses have passed in the margins of theorization and retreat of class consciousness identified with a lay downturn in class conceptualization as such.

In his understanding of the global economy, Cox depicts an image of the world in transition without a visibly defined centre of power. Up till now however, just as the economy has become more rigorous at the world stage and intensified in the hands of transnational corporations, state power too, remains a foundation of contemporary capitalism. We have seen it more obviously in Afghanistan and Iraq, where America pursued its long-held foreign policy goal of securing dominance of the global oil supplies and concurrently maximizing its influence over any existing or potential rivals. Though, state power remains a significant element for capitalism in another way too: in the domestic realm, education, transport, legal field and infrastructure; in promoting science and technology in the face of global competition; in allying and negotiating with other states in the interest of domestic capital; in disciplining the working class and restrain its unity, etc. It may prove erroneous nevertheless and again misrepresent material facts when Cox argues for example that the contemporary GPE

\footnotetext{
${ }^{43}$ Robert Cox, Global Perestroika, in Miliband \& Panitch, (1992), (eds.), The Socialist Register, p.27; also in George T. Crane \& Alba Amawi, ( $2^{\text {nd }}$ ed), Theoretical evolution of International Political Economy: A reader, (1997), Oxford: Oxford University Press. ${ }^{44}$ Robert Cox, (2002), The Political Economy of a Plural World, London, pp85.
} 
"is characterized by a "new capitalism" which opposes any form of state or interstate control or intervention". 45

\section{Forgotten Revolutionary Spirit of Gramscian Theory}

Neo-Gramscianism implicitly advanced a provocative parallelism between Gramsci's theory and the nascent global state personified in the neoliberal hegemony. Whilst the State structure depicted by Gramsci is to some extent outdated, neo-Gramscians transferred his analysis of the dynamics of hegemony to the international scale. They replaced the traditional bourgeoisie with the new transnational capitalist class, which is in the process of congealing and establishing a global state composed of diverse international institutions that help actualise and legitimise its world-view. ${ }^{46}$ NeoGramscians have gone so far to claim that 'global bourgeoisie' is producing a cultural and ideological hegemony, which is upheld by international law and institutions. Recalling the dynamics of imperialism, the domination of the new global ruling class is exercised by the more powerful Northern/Western States (i.e. European and North American) over the weaker States (e.g. African). Neo-Gramscianism echoes Gramsci in stressing the centrality of "the consensus on the form and composition of the emerging global state", as a necessary element for the maintenance of hegemony. Finally, it is argued that the ruling elite in the Third World upholds through hegemony the idea of multilateralism to their people, because this elite gains certain advantages from the existence of the international system.

Part of the reasons we have argued, why the neo-Gramscian approach stands on a wobbly position regarding the application of Gramsci's ideas to international relations is because of its rejection of a necessary aspect of Marxian thought, the paradigm of production and the belief that the industrial working class only could liberate human beings from all forms of misery; the concept of the mode of production, which Coxargues is the cause of "static and abstract" analysis. ${ }^{47}$ Often Gramsci is presented in the social sciences as a precursor of and justification for this apparent fatality. ${ }^{48}$ Other writers show this is incorrect based on Gramsci's own "detailed, accurate reconnaissance of the social classes and forces present in the society of his time". ${ }^{49}$ Cox's argument might be considered wrong, since Marxism does not envisage the concept of the mode of production as abstract types, but a totality spearheaded by inner negation towards steady transformation. Although, the dominant social force of the social relations in a mode of production inflicts limitations on the type of transformation - be that

\footnotetext{
${ }^{45}$ Robert Cox, (1994), The Crisis in World Order and the Challenge to International Organization, in Cooperation and Conflict, Vol. 29, No. 2, pp99.

${ }^{46}$ Chimni, B. S. 'International Institutions Today: An Imperial Global State in the Making' (2004) EJIL Vol. 15 No.1, 1 - 37.

${ }^{47}$ As above in, Social Forces, States and World Orders, pp94

${ }^{48}$ Morera, Esteve. (1990), Gramsci and Democracy, Canadian Journal of Political Science, 23 (1), pp 23-37 particularly pp29-30.

${ }^{49}$ Gramsci, Antonio. (1995/1999). Further Selections from the Prison Notebooks, trans., ed. Derek Boothman, ElecBook, London, transcribed from Lawrence and Wishart edition, London: pp72
} 
political, institutional, or technological - that can be adapted within their agenda. This has produced a number of negative results. The center of the debate within the Marxist analysis is shifted rather towards in favour of emphasizing more so ideas and the complex-whole concept of hegemony. Thus by focusing on the established social organization alone, neo-Gramscianism overlooks the moments of force and coercion that Gramsci argued underpin the concept of hegemony..$^{50}$ Furthermore, the exaggerated concern only with the ideology of the ruling class - largely abstracted, from the resistance that subordinate classes put against it - ignores as a result the limitations that this places to the exercise of hegemony. ${ }^{51}$ Neo-Gramscian inadequacy to position the inter-state system as contained by the totality of capitalism, in turn entails a mistaken view of the world order, characterized by, "the duality of interstatesystem and world economy", each prone to distinctive internationalizing arguments. ${ }^{52}$

Gramsci's ideas, notwithstanding the gaps found in the neo-Gramscian approach, however, hold a particular importance for contemporary IPE theory and practice. The theoretical aspect of Gramsci's argument - "the complex contradictory and discordant ensemble of the superstructures is the reflection of the ensemble of the social relations of production" - when extended to the international dimension, stresses that war and the inter-state system at one level and the global economy at another level are interdependent facets of a contradictory whole. ${ }^{53}$ Thus, Cox is mistaken, believing in a duality in place subjected to differing logics. Resisting therefore imperialism and its neo-conservative tendencies is still an imperative to the anti-capitalists' today, just as it was for Gramsci in the early twentieth century. Today Gramsci's concept of passive revolution is particularly an important contribution, in pointing to the implications of the global expansion of neoliberalism. Neoliberal global strategy, can be thought of, as a form of passive revolution, in which subordinate states, (global South), conform to structures and policies that are more in line with the common interest of the world's highly developed states: whereby the working class's most abrupt adversary, in both developed and subordinate states, remains the national ruling elite. The mounting opposition to neoliberalism by the ruling elites of the global South, echoing their independent interests, has been subdued by the common interests of the world's elites against the interests of subordinate classes. Thinking thus neoliberal global strategy (globalization), as passive revolution, meaning, that subaltern Southern classes' must espouse the ideas of the contemporary anti-capitalists' of the global perspectives, but acting at the local level, implies in fact just the same for the subordinated classes in the West.

\footnotetext{
${ }^{50}$ Randall Germain and Michael Kenny, (1998), Engaging Gramsci: International Relations Theory and the Neo-Gramscians, Review of International Studies, Vol. 24, No. 2, pp18-19.

${ }^{51}$ Alejandro Colas, The Class Politics of Globalization, in Mark Rupert and Hazel Smith (2002), Historical Materialism and Globalisation: Essays on Continuity and Change, ed, London, pp192

${ }^{52}$ As above, in Cox, Production, Power and World Order, pp107-109

${ }^{53}$ As above Prison Notebooks, (1971), pp366
} 
Gramsci recognized the fact that Italy's enemy lay at home and this motivated him of analyzing in depth the history and politics of the national social relations. He noted that the ruling class ideas had to be tackled severely, which implied for the Italian left a need of understanding the elements of 'originality and uniqueness' in national social relations in order to 'dominate them and direct them'. ${ }^{54}$ Following Marx, Gramsci signified that "it is on the level of ideologies that men become conscious of conflicts in the world of the economy". ${ }^{55}$ The struggle and hostility towards the countering of the ruling class ideas necessarily demanded the revolutionary political force that Gramsci had in mind: what Anderson called "Gramsci's effective political testament". Gramsci understood the coercive nature of the ruling elite's power and argued that "the violent conquest of power necessitates the creation by the party of the working class of an organization of the military type". ${ }^{56}$ Only from profound crisis will the prospect come for the majority of the world peoples, for them to see through the false consciousness and take action, according to their own interests. Gramsci foresaw that a revolutionary organization as such in its decisive struggle would be able to wound the bourgeois state. When that happens in any or in many of the world's advanced industrial states, only then, a fundamental move will have been made towards the global transformation that is hoped, neo-Gramscianism desires.

\section{Conclusion}

Neo-Gramscian perspectives, inevitably of course, have encountered many criticisms on their evolution, briefly concentrated on: the role of ideas and an alleged empirical pluralism that promotes ideas as an independent explanatory variable that is then given equal weight to production. ${ }^{57}$ Furthermore criticism is given to Cox's notion of the internationalisation of the state, in which the state is reduced to a transmission-belt adjusting the domestic economy to the requirements of the global economy. ${ }^{58}$ Cox's positioning of change itself then is located within a gradualist framework that does not envisage any immediate prospect of fundamental change. Consequently this has led critical IR/IPE professionals purely in the shadow of engagement with creative forms of resistance or potential alternatives to the current order. ${ }^{59}$ If no serious alternative is on the cards, is there any point in critiquing the way that capitalism functions? ${ }^{60}$ If the Marxism today appears diminished, why not accept that there is no alternative

\footnotetext{
${ }^{54}$ Prison notebooks, (1971), pp240

55 Prison Notebooks, (1971), pp162

${ }^{56}$ As above in, The Antinomies of Antonio Gramsci, (1976), pp72

${ }^{57}$ Burnham, Peter (1991) 'Neo-Gramscian Hegemony and the International Order', Capital \& Class, 45: 73-93.

${ }^{58}$ My emphasis, for a powerful critique to the Coxian interpretation see the chapter in: Panitch, Leo (1994) 'Globalisation and the State', in Panitch \& Miliband (eds) The Socialist Register: Between Globalism and Nationalism. London: Merlin Press.

${ }^{59}$ Drainville, André (1994) International Political Economy in the Age of Open Marxism, Review of International Political Economy, 1(1): 105-32.
}

${ }^{60} \mathrm{http}: / /$ www.policy-network.net/articles/4064/-What-Antonio-Gramsci-offers-to-social-democracy 
to the market orthodoxy? Without contemporary answers to these questions, critical thinking faces continuing deadlock ahead. In the current financial crisis the popularity of the left for example in Britain but also more broadly has been plummeting, largely because they have been unable to make a principled stand against those responsible for what has happened - for indeed many on the left-wing have largely embraced the same politics. The intellectual left lacks a politics that can concurrently provide a critique of capitalism and yet accept that it is the system in which they will continue to operate for the foreseeable future. Gramsci argued that although an economic crisis itself a product of the class struggle creates the potential for a political struggle, which can ultimately affect the state, if however, the political subjective force does not intervene successfully, an economic crisis will not by itself be enough in producing the transformation of society.

Why Gramsci is significant for us, is because he offers great insights, precisely into questions he was forced to confront, namely, of how popular resistance could continue to be marshalled at a time of defeat, and how to turn resistance into the kernel of a new society. The continued dependence on traditional forms of organization in the socialist movement, as well as the increasing passivity of strategic options on the Left have made incumbent a confrontation with "the one genius", as Eugene Genovese has aptly remarked "who posed and faced western socialism's most difficult problems". His concept of hegemony offers a way of thinking about creating the conditions for political change while recognising that there is little immediate chance of a major breakthrough. Gramsci sought to analyse how those in power continued to find new ways of maintaining their position even embroidered amid great crisis. Gramsci speaks both to revolutionaries who long for change but recognise it is not on the horizon, and those intellectuals who reject oppositional-ism but want to make headway against the political economic and cultural hegemony of capital. In our civil society, such institutions as the National Health Service and Welfare State arguably support the present hegemony by making immense class compromises to maintain the status quo. ${ }^{61}$ Furthermore, financial institutions play a pivotal role in maintaining bourgeois hegemony. For example, when we consider relentless advertising campaigns that offer us the chance to 'buy now, pay later' for goods such as sofas, automobiles and even our own homes, as well as the barrage of 'junk mail' enticing us to take out credit cards and loans, which are also accessible at the click of a button twenty-four hours a day via the Internet, we are in danger of falling into the trap of thinking that we cannot function without these giant capitalist corporations.

Hegemony is never stable, and this means that, however strong it appears to be however much, for example, the market is presented as the only way of organising society - it is possible to intervene to disrupt that hegemony and put forward an alternative way of looking at the world, an alternative moral and political philosophy.

${ }^{61}$ http://www.essex.ac.uk/sociology/student_journals/UG_Journal/UGJournal_Vol4/2010SC201_KeeleyKnowles. 
Gramsci understood that capitalism would always encounter crises of finance and production (i.e. boom and bust can never be a thing of the past), and he sought ways of understanding how the crises within hegemonic rule that are possible consequences of such crises could be taken as opportunities for counter-hegemonic forces to put forward their new solutions. He saw that specific forms of hegemonic rule could be remade in such moments of crisis - so that either the existing dominant class would regroup to piece together a new hegemonic strategy, or a new challenge could be made to their whole way of thinking and doing. When a crisis disrupts such a settlement - as the ongoing financial crisis - there is infinite opportunity to intervene and put forward a whole new way of thinking about and organising society. That is clearly something that has not happened and one reason for this is the huge amount of work put in by organic intellectuals of the corporate world in support of their way of making sense of the world, and the lack of a parallel strategic vision by left intellectuals. The idea of a counter-hegemonic project is to take the elements of good sense that already exist (for example social aspirations already present such as support for public services, or people's sense of immigration) and articulate them together to create new ways of making sense of the present, embodied in a political programme.

In that respect if we look more closely at home both Blair's and Cameron's political formations thus did not represent new political conjunctures, but were phases within a wider neoliberal settlement - the period of the resurgence of business and finance interests after their temporary (slight) taming after the second world war. The common sense of this whole period has been dominated by the idea that there is no alternative to the market. Thinking with Gramscian ideas allows us to get a much clearer understanding of the complexities that make up the current political situation - both in terms of the underlying features and the more subjective elements. It also alerts us to the need for intellectual work in countering the dominant current sense, but at the same time affirms to us that it is possible to do so. ${ }^{62}$ Continuation of the neoliberal politics entails a continuation or rather an escalation of accumulation by the means of dispossession. This spells an ever rising tide of resistance to which the only answer is the repression by the state powers of popular movements and the continuation of warfare that has characterised the global economy for the last thirty years. The leading capitalist countries cannot further afford feeds of capital inflows to support their own unproductive consumption, neither militarily nor in the private sector. So far the implications have been the equivalent of a structural adjustment in the global economy that has entailed an unheard degree of austerity, which have not been seen since the 1930 s crisis. The only possible alternative, albeit not permanent, within the current age of capitalistic mode of production is some sort of a similar response to the Great Depression situation that has a global reach. This means getting rid of the logic of capital circulation from its neoliberal chains and

\footnotetext{
62 http://www.policy-network.net/articles/4064/-What-Antonio-Gramsci-offers-to-social-democracy
} 
reformulating state power along much more interventionist and redistributive lines; curbing the speculative powers of finance capital and democratically controlling the overwhelming power of the 'military-industrial complex' that never ceases to dictate everything from trade to what we see, read and hear in the media. The class power ranged behind neoliberalism is formidable, though, the more problematic its form of governance appears at home and abroad, the more there will likely be division and dissent even within the elite classes over the direction that power should take. The current difficulties within the neoliberal model ant the threat it now poses to the bourgeois norms and capitalistic practises itself may even provoke the need for an alternative construction of anti-neoliberal politics: While this has not happened so far and may not be taken as determinant, it will play a huge role in our individual and collective futures.

None of the mainstream political forces that dominated politics since the second half of the twentieth century are immune from today's anti-political mood, as the low turnout in national elections' across Europe reveals. In Britain one is very likely to encounter people who say not that they wouldn't vote this or that party, but simply: we don't vote. A way is still to be discovered, in order to re-engage the millions who do not vote or even register to vote. The system in which politics is conducted by a few and economic policy skewed towards the vested interests of a few others, including media owners and the banks must end. Yet it is politics which allows most (especially the working class), to go beyond an economic corporative definition of their position, as a wage labourer, a definition remaining within the logic of capitalist relations of production. It is politics, which allows people to become leaders, builders of a new order, rather than simply rebel in a negative way against the existing one. The achievement of the political consciousness is the ability to become the theoretician, of tomorrow, of a new social formation. Gramsci's insights into the forms of a possible working class hegemony retain today their fertility for further theoretical and practical investigation, awaiting the energies and initiatives of a reviving working-class movement which alone will be able to confirm and, if necessary, to transform them in practice..$^{63}$ In line with Gramscis 'philosophy of praxis', we conclude with an indeterminate view of history, where humans play a major role in shaping their social, political and economic reality. 


\section{Bibliography}

1. Abercrombie, N. \& Hill, S. \& Turner, B. (1980), The Dominant Ideology Thesis, London: Allen \& Unwin

2. Amsden, Alice. 'Third World Industrialisation: "Global Fordism" or a New Model', New Left Review, No. 182, Jul-Aug 1990

3. Anderson, Perry. (1976), 'The Antinomies of Antonio Gramsci', in New Left Review 100, Nov-Dec, p.59

4. Arrighi Giovanni, (1994), The Long Twentieth Century, New York, pp297

5. Augelli, E. \& Murphy, C. (1988), America's Quest for Supremacy and the Third World, London: Pinter

6. Bieler, A. \& Morton, A. (2006) (eds.) Images of Gramsci, London: Routledge

7. Boothman, Derek. trans., ed 'Antonio Gramsci : Further Selections from the Prison Notebooks' ElecBook, London: transcribed from Lawrence and Wishart edition, London: (1995/1999), pp72

8. Burnham, Peter. 'Neo-Gramscian Hegemony and the International Order', Capital and Class, 45, Autumn (1991), 45: 73-93

9. Burnham, Peter. (1990), The Political Economy of Postwar reconstruction, London: Macmillan

10. Chimni, B. S. 'International Institutions Today: An Imperial Global State in the Making' (2004) EJIL Vol. 15 No.1, 1 - 37.

11. Colas, Alejandro. 'The Class Politics of Globalization', in Mark Rupert and Hazel Smith (2002), Historical Materialism and Globalisation: Essays on Continuity and Change, ed, London, pp192

12. Cox, Robert. (2002), The Political Economy of a Plural World, London, pp85.

13. Cox, Robert \& Sinclair, Timothy (eds) (1995), Approaches to World Order, Cambridge: Cambridge University Press, pp87.

14. Cox, Robert. (1994), 'The Crisis in World Order and the Challenge to International Organization', in Cooperation and Conflict, Vol. 29, No. 2, pp99

15. Cox, Robert. (1987), Production, Power and World Order: Social Forces in the Making of History, New York, pp.289.

16. Cox, Robert. 'Gramsci, Hegemony and International Relations: an Essay in Method', in Millennium: Journal of International Studies, Vol. 12, No. 2, (1983).

17. Cox, Robert. (1981) 'Social Forces, States and World Orders: Beyond International Relations Theory', Millennium: Journal of International Studies, 10(2): p129

18. Crane, G, T. \& Amawi, Alba. ( $2^{\text {nd }}$ ed), Theoretical evolution of International Political Economy: A reader, (1997), Oxford: Oxford University Press. 
19. Darel E. Paul, (2005), Rescaling International Political Economy, London: Routledge

20. Davis, Mike 'From_Fordism to Reaganism: The Crisis of American Hegemony in the 1980s', in Bush, R. \& Johnston, G. \& Coates, D. (1987), The World Order: Socialist Perspectives, Cambridge, pp8.

21. Drainville, Andre. (1994) 'International Political Economy in the Age of Open Marxism', Review of International Political Economy, 1(1): 105-32.

22. Femia, J. V. 'Gramsci, the Via Italiana, and the Classical Marxist-Leninist Approach to Revolution' Government and Opposition, 14 (Winter 1979): p83

23. Germino, Dante. (1990), Antonio Gramsci: Architect of a New Politics, Baton Rouge: Louisiana State University Press, pp14-22.

24. Germain, Randall. \& Kenny, Michael (1998), 'Engaging Gramsci: International Relations Theory and the Neo-Gramscians', Review of International Studies, Vol. 24, No. 2, pp18-19.

25. Gill, Stephen \& Law, David. (1988), The Global Political Economy: Perspectives, Problems and Policies, London: pp63.

26. Gill, Stephen. (1995), Globalisation, Market Civilisation, and Disciplinary Neoliberalism, Millenium: Journal of the International Studies 24: p422 and pp399-423.

27. Gill, Stephen. (ed.) (1993), 'Gramsci, Historical Materialism and International Relations', Cambridge: Cambridge University Press, pp56

28. Gill, Stephen. 'Intellectuals and Transnational Capital', The Socialist Register Vol. 26, (1990), pp290-1

29. Gilpin, Robert (1981) War and Change in World Politics, Cambridge: Cambridge University Press.

30. Gramsci, Antonio (1957). 'The Modern Prince and Other Writings', ed. and trans. Louis Marks, New York: International Publishers, pp30-31

31. Harman, Chris (1999), Explaining the Crisis, London: Bookmarks.

32. Hallas, Duncan. (2008) (2 ${ }^{\text {nd }}$ eds.), The Comintern: A History of the Third International, Chicago: Haymarket Books.

33. Halliday, Fred. (1994), Rethinking International Relations Basingstoke: Macmillan Press

34. Henderson, Hamish. (1988), Antonio Gramsci: Prison Letters, (ed), London: Zwan, pp214

35. Hobsbawm, Eric. (1977), Gramsci and Political theory, Marxism Today, pp20513

36. Miliband, Ralph. \& Panitch, Leo. (1992), (eds.), The Socialist Register, p.27 
37. Miliband, Ralph. (1977), Marxism and Politics, Oxford: Oxford University Press, p43.

38. Miliband, Ralph. (1973), The State in Capitalist Society, London: Quartet Books, p8

39. Morera, Esteve. (1990), 'Gramsci and Democracy', Canadian Journal of Political Science, 23 (1), pp 23-37

40. Paul, D. (2005), Rescaling International Political Economy, London: Routledge

41. Panitch, Leo. 'Globalisation and the State', in Panitch \& Miliband (eds) The Socialist Register: Between Globalism and Nationalism. (1994) London: Merlin Press.

42. Picciotto, Sol. (1991), 'The Internationalization of the State' Review of Radical Political Economics, Vol. 22 28-44 SAGE

43. Quintin Hoare, Q. \& Smith, G. N. Selections from the Prison Notebooks of Antonio Gramsci, (1971), trans, and eds. London: Lawrence and Wishart

44. Robinson, W. (1996), Promoting Polyarchy, Cambridge: Cambridge University Press

45. Rosenberg, Justin. (1994), The Empire of Civil Society: A Critique of the Realist Theory of International Relations London: Verso

46. Rupert, Mark. (2005). 'Reading Gramsci in an Era of Globalising Capitalism', Critical Review of International Social and Political Philosophy, 8, 4, pp483-497

47. Rupert, Mark (1995), Producing Hegemony, Cambridge: Cambridge University Press

48. Rupert, Mark 'Alienation, Capitalism and the Inter-state System: Towards a Marxian/Gramscian Critique', in Stephen Gill (1993), Gramsci, Historical Materialism and International Relations, Cambridge: Cambridge University Press.

49. Skocpol, Theda. (1979), States and Social Revolutions, Cambridge: Cambridge University Press

50. Therborn, Goran. (1980), The Ideology of Power and the Power of Ideology, London: Verso 


\section{Website Sources}

1. Thomas, Martin "The revolutionary socialist as democratic philosopher". (Review of "The Gramscian Moment" by Peter Thomas) WORKER'S LIBERTY. Last accessed 05-10-2012

2. <http://www.workersliberty.org/story/2011/06/15/gramsci-revolutionarysocialist-democratic-philosopher>

3. Bieler, A \& Morton, A.D. "Theoretical and Methodological Challenges of neoGramscian Perspectives in International Political Economy" ISG Articles, last accessed 05-10-12

4. <http://www.internationalgramscisociety.org/resources/online_articles/ articles/bieler_morton.shtml>

5. Davison, Sally. "What Antonio Gramsci offers to social democracy" Policy Network,_10-10-2011, last accessed 0510-2012

6. <http://www.policy-network.net/articles/4064/-What-Antonio-Gramscioffers-to-social-democracy> 